\title{
ENTREPRENEURS AS INNOVATORS: A MULTI-COUNTRY STUDY ON ENTREPRENEURS' INNOVATIVE BEHAVIOUR
}

\author{
Martin Lukeš*
}

\begin{abstract}
:
Since Schumpeter, entrepreneurs and innovative activities belong together. Innovativeness as a personality trait is also found to be related to entrepreneurial status and business success. However, not much is known about the specific facets of the entrepreneur's innovative behaviour. This study aims first at better understanding how entrepreneurs differ from managers in the various areas of their innovative behaviour at work. Second, how this behaviour differs for entrepreneurs who have and do not have employees. Representative samples of the working population from Germany, the Czech Republic, Italy and Switzerland ( $N=3508)$ were interviewed with the use of the Innovative Behaviour Inventory. Individuals involved in independent entrepreneurial activities create new ideas and attempt to overcome obstacles during implementation more than employed individuals. People who manage other people communicate new ideas and seek to engage other individuals in the implementation of new ideas more than those without subordinates. Finally, what differentiates entrepreneurs from all other groups is their higher involvement in preparatory activities that start the implementation of new ideas. Overall, these differences led to the foremost position of entrepreneurs in achieving the innovation outputs.
\end{abstract}

Keywords: entrepreneur, self-employed, innovation process, innovative behaviour, intergroup comparisons, representative samples

JEL Classification: L26, O31

\section{Introduction}

Since Schumpeter (1934), entrepreneurs are considered to be catalysts of change, creative destructors and innovators in general. Management texts (such as Drucker, 1985), empirical studies (Mueller, Thomas, 2000), and meta-analyses (Rauch, Frese, 2007) identify innovativeness as one of the core features of entrepreneurial personality. However, innovativeness is typically analysed as a trait and is closely related to the interest of an entrepreneur in innovations. It is usually conceptualized broadly, often as a uni-dimensional factor as in the case of Jackson (1994), without understanding the various facets of innovative behaviour in a rather complex innovation process.

* Martin Lukeš, University of Economics, Prague, nam. W. Churchilla 4, 13067 Prague 3, Czech Republic (lukesm@vse.cz). This study was supported by the European Commission; project CID Culture and Innovation Dynamics: Explaining the Uneven Distribution of Human Knowledge (FP6 - 043345). An earlier version of this paper was presented at Rencontres de St. Gall 2010, 8-10 Sept. 2010, St. Gallen. Thanks to Richard Brunet-Thornton for revising the manuscript. 
On the other hand, innovation management literature deals with the topics of what the innovation process is (Farr, Sin, Tesluk, 2003), and how to manage it effectively (Bernstein, Singh, 2006). Such knowledge can be well applied in corporate settings, but tells little about the activities independent entrepreneurs do. It also focuses on the system and less on the activities of an innovating individual.

Therefore, there is a value in better understanding of what entrepreneurs do when they innovate and how they differ in their innovative behaviour when compared with other individuals, especially with their managerial counterparts. Such knowledge can be utilized by teachers and consultants who support entrepreneurs in their innovative efforts. Moreover, not all entrepreneurs innovate to the same extent (Miner, 2000). Substantial innovation-related differences may exist, for example, between the owner of an IT company experiencing rapid growth and a self-employed webpage programmer.

The study's goal is, primarily to better understand how entrepreneurs differ from managers and other employees in the diverse areas of innovative behaviour at work. The secondary objective is to differentiate between entrepreneurs themselves and to discover differences and similarities in their innovative behaviour.

\section{Entrepreneurs and Innovative Behaviour}

Generating or recognizing novel and useful ideas that may potentially be developed into new goods or services attractive to some identifiable market remains a key challenge for entrepreneurs. Having identified these opportunities, entrepreneurs must determine how to successfully realise the project (Ward 2004).

Drucker (1985) considers innovation as being the specific tool by which entrepreneurs exploit opportunities. The research to date focuses mainly on innovativeness as a personal trait (Rauch, and Frese, 2007; Mueller, and Thomas 2000) or, alternatively, innovativeness at the firm-level (Covin, Slevin, 1989; Rauch, Wiklund, Lumpkin, Frese, 2009).

Innovativeness can be described as willingness and interest to seek original ways of action. This conceptualization does not imply the introduction of innovative products, but rather, more a preference to engage in creativity and experimentation (Rauch, 2010). Innovativeness assists entrepreneurs to recognize valuable opportunities and to search for new ways of task completion (Ward, 2004).

Research indicates that entrepreneurs tend to be more innovative than others. Carland and Carland (1991) suggest that U.S. entrepreneurs have significantly higher levels of preference for innovation than managers. Similarly, entrepreneurs score higher on Kirton's adaption-innovation scale (Kirton, 1976) than general managers of large organizations in the Buttner and Gryskiewicz study (1993). Furthermore, a recent Czech study implies that marketing managers in larger companies lack creativity (Hořejš, Karlíček, 2011). Finally, Shane, Kolvereid, and Westhead (1991) report that 
the desire to be innovative and at the forefront of new technology was frequently given as a reason for starting a business in all three countries analysed in their study.

Recent meta-analysis demonstrates that entrepreneurs are more innovative than others. Furthermore, innovativeness is positively related to the decision to start a business and is also positively and directly correlated with business success (Rauch, Frese, 2007). Interestingly, entrepreneurs' innovativeness produces higher relationships with business success as compared to the relationship between firm-level innovations including the introduction of new products, services, processes and markets, and success (Rauch, 2010; Rosenbusch, Brinckmann, Bausch, 2010).

At the firm-level, innovativeness can be defined as the predisposition to engage in creativity and experimentation through the introduction of new products and services as well as technological leadership through Research and Development (R\&D) in new processes (Rauch et al., 2009). In their meta-analysis, Rauch et al. confirm the positive correlation between entrepreneurial orientation based on Covin and Slevin's scale, and firm performance. Innovativeness is the individual component of the entrepreneurial orientation construct that correlates the most frequently with the firm performance (corrected $r=0.195$ ).

Rauch (2010) questions whether, and if so, how innovativeness at the firm-level is dependent on the innovativeness of owners. In other words, there is a gap between the innovativeness as a trait and firm-level innovation. This gap can be closed by better understanding the innovative behaviour of an entrepreneur as mediator between a personal trait and firm-level innovativeness. The personality of an individual entrepreneur influences his/her behaviour consequently impacting the firm and the potential for success. As a result, it is interesting to focus more on this missing link.

\section{Measuring the Innovative Behaviour}

Based on the process oriented definition of workplace innovation (West, Farr, 1990), innovation may be defined as the process of new idea creation or adoption, and a subsequent effort to develop this into a new product, service, process or business model with an expected added value for a potential user.

Such a definition enables focus on the acting individual in the different phases of the innovation process. It permits the involvement of various innovation types, not only radical innovations, but also the substantially more frequent incremental innovations. In the innovation process as a whole, six distinct activities of innovating individuals are identified. The innovation process at work originates either by the independent creation of a new idea (Amabile et al., 1996) or by a search for new ideas (Kelley, Peters, and O'Connor, 2009). Then, there is a need to communicate potentially interesting idea to others (Binnewies, Ohly, Sonnentag, 2007). The latter may consist of employees or business partners in the case of entrepreneurs, or colleagues and managers for employed individuals. If the idea proves to be feasible and is approved, the preparation 
of implementation may start (Baer, Frese, 2003). The innovation champion usually involves other stakeholders and overcomes obstacles during the implementation until finally delivering the results of previous innovative activities (Howell et al., 2005). The process is not linear, and includes many feedback loops with phases often in parallel. For example, latter implementation phases also include the aspect of idea generation when new ways of implementation or resource acquisition must be found.

The issue becomes how to gauge innovation in line with this conceptualization. Existing person-related innovation measures can be largely grouped into three categories:

1. measures of innovativeness as a personality trait,

2. general measures of employee innovative behaviour, and

3. measures of innovation champion behaviour.

In the first category, frequently used measure of general innovativeness is Kirton's Adaption - Innovation Inventory (Kirton, 1976) that differentiates innovators form adaptors on three scales: originality, efficiency and group conforming. The second measure is the innovativeness scale from the Jackson Personality Inventory (Jackson, 1994). However, none of these scales focuses on innovative behaviour at work.

In regards to the general innovative behaviour of an employee in the work context, are the well-established innovative behaviour measures from Scott and Bruce (1994) and Janssen (2003), as well as the creativity scale by Baer and Oldham (2006). Nevertheless, these scales quantify solely a general innovative behaviour at work by one overall factor and do not permit a more detailed perspective on innovation.

The third group of existing measures focuses exclusively on the behaviour of an innovation champion. Shane, Venkataraman and MacMillan (1995) suggest a measure of three championing factors of autonomy, cross-functional appeal, and locus of support. In a recent study, Howell, Shea and Higgins (2005) develop and validate a champion behaviour measure that captures three different facets comprising the expression of enthusiasm and confidence on innovation success, persistence under adversity, and the assignment of the appropriate individuals for the task. These measures, however, do not focus on the initiation phases of the innovation process and, moreover, focus rather on R\&D personnel.

As there is no measure that would cover the specific innovative behaviours during all phases of the innovation process while at the same time enabling to include general population, a new measure of innovative behaviour at work, the Innovative Behaviour Inventory was recently established. That assists to understand both the initiation aspects of idea creation, search, and communication, and the implementation encompassing preparatory activities, the involvement of others, and the overcoming of obstacles (Lukeš, Stephan, Černíková, 2009). This inventory offers the possibility to initiate a study on the general adult population, thus allowing comparisons of entrepreneurs with other groups. Furthermore, such an instrument allows us to build more refined models and hypotheses regarding innovative behaviour. 
Based on previous studies (Carland, Carland, 1991; Buttner, Gryskiewicz, 1993), meta-analysis (Rauch, Frese, 2007), and described conceptualization, the first hypothesis states:

H1: within the work environment, entrepreneurs behave more innovatively than employees and also more than managers, that is, they are more engaged in creating and searching for new ideas, communicating them to others, initiating their implementation, involving others, and overcoming obstacles in the implementation, therefore achieving more innovation results.

\section{Entrepreneurs and the Self-Employed}

However, all entrepreneurs are not innovative to the same extent. Tuunanen and Hyrsky (1997) claim that both Finnish and American entrepreneurs who report their primary objectives to be profit and growth scored higher on Jackson's innovativeness scale than did those reporting family income as their primary goal. Similarly, Carland, Carland, Hoy and Boulton (1988) discover that entrepreneurs who establish and manage a business for the principal purposes of profit and growth have a higher preference for innovation than other small business owners.

Finally, scholars have different approaches as to what constitutes the entrepreneur. The Global Entrepreneurship Monitor project, for example, focuses on entrepreneurial activity regardless of the size of the business. That is, any individual engaged in any kind of (independent) entrepreneurial activity represents an entrepreneur (Lukeš, Jakl, 2012). The other approach focuses on individuals who pursue entrepreneurial opportunities without regard to currently controlled resources (Stevenson, Jarillo, 1990). Implicitly, there is more determination to pursue the opportunity, to take risks, to employ personnel, and ultimately to grow. Consistent with past research on business owners (Utsch et al., 1999), distinction is drawn between self-employed freelancers with no employees, and business owners/entrepreneurs, with at least one employee. Presumed differences in the innovative behaviour between these groups originate from varying approaches to motivation and business management, but specifically due to the wide-ranging options to engage other people in the development of their new ideas. It is substantially easier for entrepreneurs with employees; therefore these differences should be significant.

In this study "entrepreneurs with employees" are defined as owners and managers of their own companies who employ others. Whereas, persons engaged in entrepreneurial activities on their own, without employees, working for themselves and not for an employer are "self-employed without employees". A person employed in a company owned by another who has at least one subordinate is "employed manager". Other working individuals are referred to as "employees". 
Corresponding with the previous text, the second hypothesis states:

$\mathrm{H}_{2}$ : self-employed individuals demonstrate less innovative behaviour at work than entrepreneurs with employees in the areas involving interpersonal communication; especially, they are less engaged in communicating new ideas and in involving others in their implementation.

\section{Methods}

The Innovative Behaviour Inventory covers areas of work-related innovative behaviour and consists of seven subscales: Creating ideas, Searching for ideas, Communicating ideas, Preparing implementation, Involving others, Overcoming obstacles and Innovations outputs. The first six subscales constitute a second-order factor Innovative behaviour at work that is positively and significantly related with the subscale of Innovation outputs (Lukeš, Stephan, Nový, Lorencová, 2010). The inventory is reliable and shows satisfactory factorial, criterion, convergent, and discriminant validity (Lukeš, Stephan, Černíková, 2009). It was also found to be measurement invariant in seven countries (Lukeš et al., 2010).

The full inventory including all 23 items (answered on 1 to 5 Likert-type scale) is described in Lukeš, Stephan, and Černíková (2009). The examples of items for all scales as well as scale reliabilities are presented in Table 1.

Table 1

Item Examples and Scale Reliabilities

\begin{tabular}{|c|c|c|c|}
\hline Scale & $\begin{array}{l}\text { No. of } \\
\text { items }\end{array}$ & Item example & $\begin{array}{l}\text { Cronbach's } \\
\text { alpha }\end{array}$ \\
\hline Creating ideas & 3 & $\begin{array}{l}\text { When something does not function well at work, I try } \\
\text { to find new solution. }\end{array}$ & 0.69 \\
\hline $\begin{array}{l}\text { Searching for } \\
\text { ideas }\end{array}$ & 3 & $\begin{array}{l}\text { I try to get new ideas from colleagues or business } \\
\text { partners. }\end{array}$ & 0.72 \\
\hline $\begin{array}{l}\text { Communicating } \\
\text { ideas }\end{array}$ & 4 & $\begin{array}{l}\text { I try to show my colleagues positive sides of new } \\
\text { ideas. }\end{array}$ & 0.84 \\
\hline $\begin{array}{l}\text { Preparing } \\
\text { implementation }\end{array}$ & 3 & $\begin{array}{l}\text { I develop suitable plans and schedules for the } \\
\text { implementation of new ideas. }\end{array}$ & 0.78 \\
\hline Involving others & 3 & $\begin{array}{l}\text { When I have a new idea, I look for people who are } \\
\text { able to push it through. }\end{array}$ & 0.75 \\
\hline $\begin{array}{l}\text { Overcoming } \\
\text { obstacles }\end{array}$ & 4 & I usually do not finish until I accomplish the goal. & 0.85 \\
\hline $\begin{array}{l}\text { Innovation } \\
\text { outputs }\end{array}$ & 4 & $\begin{array}{l}\text { I was often successful at work in implementing my } \\
\text { ideas and putting them in practice. }\end{array}$ & 0.80 \\
\hline
\end{tabular}




\section{Sample}

In order to avoid a potential cultural bias, the data gathering was conducted on representative samples of population within the economically active age of 18-64 years in four countries - the Czech Republic, Germany, Switzerland, and Italy. The sample representativeness is ensured by mutually-tied quotas (gender, age, educational level, region and the size of the place of residence) based on sociodemographic data published for each country by a central statistical authority such as, the Czech Statistical Office. The sample consists of 4795 adults from the Czech Republic (N=1004), Germany $(\mathrm{N}=1285)$, Italy $(\mathrm{N}=1256)$, and Switzerland $(\mathrm{N}=1250)$. The samples are representative for each country. The validation of the representativeness of the samples used $\chi^{2}$ tests of a good fit with theoretical frequencies.

The data were gathered between May and July 2008 using the CATI (Computer Assisted Telephone Interviewing) technique. The average duration of the interview was approximately 10 minutes. The selection procedure was performed by dialling of randomly generated phone numbers, and quota limits control. Concerning particular countries, the response rate (measured as accepted interviews divided by accepted plus rejected interviews) was 58\% in the Czech Republic, $65 \%$ in Germany, $34 \%$ in Italy, and $60 \%$ in Switzerland.

In this study, the sample of actively working population, that is, people currently employed or self-employed, excluding students, unemployed, housewives, and pensioners is used. This leads to the reduced sample size of $\mathrm{N}=3508$ individuals $(\mathrm{N}=229$ entrepreneurs, $\mathrm{N}=340$ self-employed, $\mathrm{N}=974$ managers and $\mathrm{N}=1965$ employees).

\section{Results}

Table 2 illustrates the significant differences between the groups (entrepreneurs, self-employed, managers, and employees) in all the scales deployed. Entrepreneurs with employees are characterized by the highest means indicating the most innovative behaviour in all the seven scales and employees without subordinates are in general the group with the least innovative behaviour. The only exception is the scale "Involving others" where self-employed individuals have the least innovative result.

Moreover, overall significant differences do not change when the analysis is performed for individual countries; in that the same significant differences between the groups exist in the Czech Republic, as well as in Switzerland and in Italy. The same is true for five scales in the German sample. The exceptions are the remaining two scales, Idea search and Involving others, that reveal no significant differences between the four groups in the German model. 
Table 2

Overall Innovative Behaviour Differences between Entrepreneurs, Self-employed, Managers, and Employees

\begin{tabular}{|c|c|c|c|c|c|c|c|c|c|c|c|c|c|c|c|}
\hline & \multicolumn{3}{|c|}{$\begin{array}{l}\text { Entrepreneurs with } \\
\text { employees }\end{array}$} & \multicolumn{3}{|c|}{$\begin{array}{c}\text { Self-employed } \\
\text { without employees }\end{array}$} & \multicolumn{3}{|c|}{$\begin{array}{l}\text { Employed } \\
\text { managers }\end{array}$} & \multicolumn{3}{|c|}{$\begin{array}{l}\text { Employees without } \\
\text { subordinates }\end{array}$} & \multirow[t]{2}{*}{$F(d f=3)$} & \multirow[t]{2}{*}{$p$} & \multirow[t]{2}{*}{$E_{t a}{ }^{2}$} \\
\hline & $N$ & $M$ & $S D$ & $N$ & $M$ & $S D$ & $N$ & $M$ & $S D$ & $N$ & $M$ & $S D$ & & & \\
\hline $\begin{array}{l}\text { Creating } \\
\text { ideas }\end{array}$ & 219 & 4.29 & .54 & 340 & 4.20 & .76 & 974 & 4.04 & .74 & 1965 & 3.85 & .83 & 36.42 & .000 & .030 \\
\hline $\begin{array}{l}\text { Searching } \\
\text { for ideas }\end{array}$ & 217 & 4.11 & .81 & 324 & 4.03 & .85 & 970 & 4.03 & .75 & 1939 & 3.84 & .82 & 15.46 & .000 & .013 \\
\hline $\begin{array}{l}\text { Communi- } \\
\text { cating ideas }\end{array}$ & 153 & 4.12 & .90 & 233 & 3.86 & 1.01 & 967 & 4.11 & .80 & 1926 & 3.81 & .87 & 29.52 & .000 & .026 \\
\hline $\begin{array}{l}\text { Preparing } \\
\text { implemen- } \\
\text { tation }\end{array}$ & 213 & 3.80 & 1.09 & 321 & 3.48 & 1.28 & 948 & 3.37 & 1.21 & 1889 & 2.85 & 1.29 & 58.00 & .000 & .049 \\
\hline $\begin{array}{l}\text { Involving } \\
\text { others }\end{array}$ & 202 & 3.94 & .92 & 302 & 3.66 & 1.08 & 972 & 3.90 & .86 & 1937 & 3.71 & .96 & 14.52 & .000 & .013 \\
\hline $\begin{array}{l}\text { Overcoming } \\
\text { obstacles }\end{array}$ & 218 & 4.29 & .65 & 339 & 4.07 & .85 & 973 & 3.82 & .82 & 1953 & 3.62 & .86 & 52.10 & .000 & .043 \\
\hline $\begin{array}{l}\text { Innovation } \\
\text { outputs }\end{array}$ & 229 & 4.15 & .65 & 292 & 3.97 & .83 & 968 & 3.68 & .86 & 1911 & 3.29 & .93 & 119.88 & .000 & .096 \\
\hline
\end{tabular}

1 = the least innovative, 5 = the most innovative; the most innovative results marked bold, the least innovative marked italics

Controlled for education, branch, gender and culture (education level taken as a covariate, for branch, gender and culture dummy variables created). Sample sizes differ due to the missing data.

The pair comparisons expose significant variances between the individual groups in all seven subscales (cf. Table 3). Firstly, entrepreneurs and self-employed originate new ideas more than managers and employees, and managers develop new ideas more than employees. Secondly, employees search for new ideas less than entrepreneurs, self-employed and managers. Thirdly, entrepreneurs and managers communicate new ideas more than the self-employed and employees. Fourthly, entrepreneurs are the most active in initiation of new ideas implementation. The self-employed and managers initiate the implementation of new ideas less than entrepreneurs but more than employees. Fifthly, entrepreneurs and managers involve others in new idea implementation more than the self-employed and employees. Sixthly, entrepreneurs and the self-employed overcome obstacles the most efficiently. Managers overcome obstacles better than employees, but not as well as the remaining two groups. Finally, in regards to the innovation outputs, entrepreneurs are in first place, followed by the self-employed, with managers at third and employees in last position. 
Table 3

Intergroup Comparisons of Innovative Behaviour Differences

\begin{tabular}{|c|c|c|c|c|c|c|c|c|c|c|c|c|}
\hline & \multicolumn{2}{|c|}{ ENTR vs. EMPL } & \multicolumn{2}{|c|}{ MANA vs. EMPL } & \multicolumn{2}{|c|}{ SELF vs. EMPL } & \multicolumn{2}{|c|}{ ENTR vs. MANA } & \multicolumn{2}{|c|}{ ENTR vs. SELF } & \multicolumn{2}{|c|}{ SELF vs. MANA } \\
\hline & $F(d f=1)$ & $E T A^{2}$ & $F(d f=1)$ & $E T A^{2}$ & $F(d f=1)$ & $E T A^{2}$ & $F(d f=1)$ & $E T A^{2}$ & $F(d f=1)$ & $E T A^{2}$ & $F(d f=1)$ & $E T A^{2}$ \\
\hline $\begin{array}{l}\text { Creating } \\
\text { ideas }\end{array}$ & $49.51^{\star \star *}$ & .022 & $27.41^{\star \star \star}$ & .009 & $60.79^{* * *}$ & .026 & $12.09^{* \star *}$ & .010 & \multicolumn{2}{|c|}{ n.s. } & $16.78^{\star \star *}$ & .013 \\
\hline $\begin{array}{l}\text { Searching } \\
\text { for ideas }\end{array}$ & $16.86^{\star \star \star}$ & .008 & $30.58^{\star \star \star}$ & .010 & $12.98^{\star \star \star \star}$ & .006 & \multicolumn{2}{|c|}{ n.s. } & \multicolumn{2}{|c|}{ n.s. } & \multicolumn{2}{|c|}{ n.s. } \\
\hline $\begin{array}{l}\text { Communi- } \\
\text { cating ideas }\end{array}$ & $19.34^{* * *}$ & .009 & $78.76^{\star * *}$ & .027 & \multicolumn{2}{|c|}{ n.s. } & \multicolumn{2}{|c|}{ n.s. } & $9.03^{\star *}$ & .024 & $18.15^{\star \star \star}(-)$ & .015 \\
\hline $\begin{array}{l}\text { Preparing } \\
\text { implemen- } \\
\text { tation }\end{array}$ & $100.75^{\star * \star}$ & .046 & $86.35^{\star \star *}$ & .030 & $51.01^{* * *}$ & .023 & $15.29^{* * *}$ & .013 & $10.17^{\text {** }}$ & .019 & n.s. & \\
\hline $\begin{array}{l}\text { Involving } \\
\text { others }\end{array}$ & $12.20^{* * *}$ & .006 & $29.23^{\text {***}}$ & .010 & \multicolumn{2}{|c|}{ n.s. } & \multicolumn{2}{|c|}{ n.s. } & $13.36^{\star \star *}$ & .026 & $25.67^{\star * *}(-)$ & .020 \\
\hline $\begin{array}{l}\text { Overcoming } \\
\text { obstacles }\end{array}$ & $92.68^{\star \star *}$ & .041 & $24.21^{\text {***}}$ & .008 & $71.62^{\star \star \star *}$ & .031 & $40.82^{\star \star \star}$ & .033 & \multicolumn{2}{|c|}{ n.s. } & $20.23^{\star \star \star}$ & .016 \\
\hline $\begin{array}{l}\text { Innovation } \\
\text { outputs }\end{array}$ & $194.09^{* * *}$ & .084 & $138.38^{* * *}$ & .046 & $142.21^{* * *}$ & .061 & $47.43^{* * *}$ & .038 & $5.97^{*}$ & .012 & $16.08^{\star \star *}$ & .013 \\
\hline
\end{tabular}

$p<.001^{* * *}, p<.005^{* *}, p<.05^{*} ;(-)$ means significant in the opposite direction; ENTR - entrepreneurs, MANA managers, SELF - self-employed, EMPL - employees

Controlled for education, branch, gender and culture (education level taken as a covariate, for branch, gender and culture dummy variables created).

\section{Discussion}

This study explores the differences in innovative behaviour between entrepreneurs opposite to employees and managers. It also differentiates between entrepreneurs with employees and self-employed individuals without subordinates. In contrast to prior research it focuses in more detail on the various facets of work-related innovative behaviour. The deeper understanding of these facets and the differences between the groups are practical for entrepreneurship training, and for consultation purposes.

The first hypothesis focuses on the expected differences between entrepreneurs with a more innovative behaviour expected and employees and managers with a less innovative behaviour anticipated. The findings confirm the leading position of entrepreneurs who have employees in innovative behaviour. When compared with employees, entrepreneurs are characterized by the higher levels of innovative behaviour in all the phases within the innovation process. When compared to managers, they exhibit higher levels of idea generation, implementation preparatory activities, overcoming obstacles, and achieving innovation outputs. On the other hand, significant differences do not exist in the idea search, communicating ideas and involving others.

The entrepreneurs' stronger position in idea generation may be attributed to their higher creativity and innovativeness as a personal trait (Rauch, Frese, 2007). Also, they have the possibility to generate ideas as a daily activity, with no requirements from a superior to do something else. Alternatively, they may have higher internal motivation to do so (Shane, Kolvereid, Westhead, 1991). In implementation preparatory activities and overcoming obstacles, there is a strong influence of a proactive personality that 
is typical to entrepreneurs. Personal initiative is characterized as the behaviour that is self-starting, pro-active and overcomes barriers (Frese, Fay, 2001). Also, in some cases, managers will not be allowed to pursue the opportunity; whereas the entrepreneur has more freedom to take such a decision. Finally, the better innovation outputs of entrepreneurs are in line with previous findings that relate entrepreneurs' innovativeness with business success (Rauch, Frese, 2007). In addition the entrepreneurs have the higher influence, when compared with employed managers, on their organizations.

On the other hand, entrepreneurs and managers do not significantly differ in the area of idea search. Managers, in comparison with entrepreneurs, could compensate their lower creativity by searching for ideas within their environment. Also, the inspiration provided by existing successes may assist in promoting the suggested idea and increase the chance of approval from their superiors. Entrepreneurs and managers also do not differ in the areas including interpersonal communication, i.e., in communicating ideas and involving others. These activities are a necessary component of the manager's job. Communications, as well as allocating tasks, are core activities that a manager performs.

The second hypothesis is that entrepreneurs who employ other people are more engaged in the innovation process phases involving interpersonal communication than self-employed individuals who do not employ anybody else. As anticipated, entrepreneurs are significantly higher in the communication of new ideas to the others and in involving other people in the implementation process than are the self-employed. They are also higher in achieving innovation outputs and in implementation preparatory activities that include planning, resource acquisition and looking for new ways of implementation. This may be related to the concept of proactive personality (Frese, Fay, 2001) along with the planning styles of entrepreneurs. Past research discloses the connection of elaborate and opportunistic planning to business success, and on the other hand, the relationship between reactive planning and a lower success rate (Frese et al. 2007). In this instance, having or not having an employee may be considered as a rough proxy for business success.

To summarize the main conclusions, individuals involved in independent entrepreneurial activities with or without employees create more ideas. They also try to overcome obstacles during implementation more than employed individuals. People, who manage others, regardless as to whether they own the company, communicate new ideas and engage others in new idea implementation more than individuals who have no subordinates. Finally, what differentiates entrepreneurs with employees from all groups is the higher involvement in implementation preparatory activities. Overall, these differences lead to the leading position of entrepreneurs in achieving the innovation outputs.

\section{Limitations}

The study has several limitations. First of all, the self-reported measure of innovative behaviour is used that constitutes a potential mono-method bias. However, objective data for establishing the criterion validity of the Innovative Behaviour Inventory are used in a previous study (Lukeš, Stephan, Černíková, 2009). Secondly, one item in the, 
Communicating ideas scale is more fitting to a corporate environment as is illustrated by more missing values in the samples of entrepreneurs and the self-employed. Therefore, it requires reformulation in future studies on entrepreneurs.

Thirdly, the approach lacks assumptions on the relative value of incremental versus radical innovations, namely, individuals with radical innovations would probably score comparably with ones developing smaller new ideas. Nevertheless, the radical innovations are scarce and it is hard to measure "radicalism". A fully different research design would have to be used involving face-to-face interviews targeting specific samples of R\&D specialists and entrepreneurs renowned for their innovation. Fourthly, the generalizability of the findings is limited, as the study was done only in four European countries. Future studies should include various countries outside Europe. Finally, the cross-sectional research design limits the ability to determine causation. Future studies might include longitudinal designs and objective measures of innovative activity results.

\section{Practical implications}

Entrepreneurs may focus on the phase of implementation preparatory activities that differentiates them from other groups. This is associated to previous findings from Frese and his colleagues in that personal initiative and elaborate planning influence positively business success (Frese, Fay, 2001; Frese et al., 2007). Both personal initiative and the planning approach can be learnt and improved.

For managers who wish to become more engaged in innovative and/or entrepreneurial activities, the same focus is recommended. Also, to overcome somewhat a lower idea creation capability, it may be recommended to use special creativity encouraging techniques such as brainstorming or facilitated idea generation sessions, or alternatively, to position oneself in a work role that offers more opportunities for idea creation.

The study also identifies potential pitfalls for self-employed individuals who have no employees, stemming from the fact of an insufficient amount of people at hand. Engagement in both formal and informal networks and the use of external advisors eliminates this disadvantage.

Finally, all of these recommendations can be also used in entrepreneurship education as well as in courses focused on unemployed individuals who contemplate starting an independent activity. Even individuals, who are not much creative, can develop proficiency in other activities related to the innovation process and achieve success. Not only the idea, but also implementation matters.

\section{Conclusion}

The study confirms and further develops the Schumpeterian view of entrepreneurs as innovators and assists to comprehend what the facets of their innovative behaviour are due to the use of the Innovative Behaviour Inventory. It also differentiates entrepreneurs with employees from self-employed freelancers with regard to their innovative 
behaviour. Entrepreneurs are the leading group in innovative behaviour at work even when compared with managers. Independent entrepreneurs with or without employees are more engaged in creating ideas and overcoming obstacles when compared to employed individuals. People, who manage others, regardless whether or not they own the company, communicate new ideas more and also try to engage others in new idea implementation. It can be difficult for the self-employed. Understanding the differences in innovative behaviour may be utilised in entrepreneurship related training in order to highlight facets of the innovation process that might be otherwise neglected.

\section{References}

Amabile, T. M., Conti, R., Coon, H., Lazenby, J., Herron, M. (1996), "Assessing the Work Environment for Creativity." Academy of Management Journal, Vol. 39, pp. 1154-1184.

Baer, M., Frese, M. (2003), "Innovation is Not Enough: Climates for Initiative and Psychological Safety, Process Innovations, and Firm Performance." Journal of Organizational Behaviour, Vol. 24, pp. 45-68.

Baer, M., Oldham, G. R. (2006), "The Curvilinear Relation between Experienced Creative Time Pressure and Creativity: Moderating Effects of Openness to Experience and Support for Creativity." Journal of Applied Psychology, Vol. 91, pp. 963-970.

Bernstein, B., Singh, P. J. (2006), "An Integrated Innovation Process Model Based on Practices of Australian Biotechnology Firms." Technovation, Vol. 26, pp. 561-572.

Binnewies, C., Ohly, S., Sonnentag, S. (2007), "Taking Personal Initiative and Communicating about Ideas: What is Important for the Creative Process and for Idea Creativity?" European Journal of Work and Organizational Psychology, Vol. 16, pp. 432-455.

Buttner, E. H., Gryskiewicz, N. (1993), "Entrepreneurs' Problem-solving Styles: An Empirical Study Using the Kirton Adaption/Innovation Theory." Journal of Small Business Management, Vol. 31, No. 1, pp. 22-31.

Carland, J. W., Carland, J. C., Hoy, F., Boulton, W. R. (1988), "Distinctions between Entrepreneurial and Small Business Ventures." International Journal of Management, Vol. 5, No. 1, pp. 98-103.

Carland, J. C., Carland, J. W. (1991), "An Empirical Investigation into the Distinctions between Male and Female Entrepreneurs and Managers." International Small Business Journal, Vol. 9, No. 3, pp. 62-72.

Covin, J. G., Slevin, D. P. (1989), "Strategic Management of Small Firms in Hostile And Benign Environments." Strategic Management Journal, Vol. 10, pp. 75-87.

Drucker, P. (1985), Innovation and entrepreneurship: Practice and principles. New York: Harper and Row.

Farr, J. L., Sin, H.-P., Tesluk, P. E. (2003), "Knowledge Management Processes and Work Group Innovation." In L. V. Shavinina (Ed.), The international handbook on innovation (pp. 574-586). New York: Elsevier Science.

Frese, M., Fay, D. (2001), "Personal Initiative: An Active Performance Concept for Work in the 21 century.” In B. M. Staw, R. M. Sutton (Eds.), Research in Organizational Behavior, Vol. 23, pp. 133-187.

Frese, M., Krauss, S., Keith, N., Escher, S., Grabarkiewicz, R., Luneng, S. T. et al. (2007), "Business Owners' Action Planning and Its Relationship to Business Success in Three African Countries." Journal of Applied Psychology, Vol. 92, pp. 1481-1498.

Janssen, O. (2003), "Innovative Behaviour and Job Involvement at the Price of Conflict and Less Satisfactory Relations with Co-workers." Journal of Occupational and Organizational Psychology, Vol. 76, pp. 347-364. 
Hořejš, N., Karlíček, M. (2011), „Český manažer marketingu chce být kreativní. Ale jen do výše hypotéky." Strategie, Vol. 6, pp. 60-61.

Howell, J. M., Shea, C. M., Higgins, C. A. (2005), "Champions of Product Innovations: Defining, Developing, and Validating a Measure of Champion Behaviour." Journal of Business Venturing, Vol. 20, pp. 641-661.

Kelley, D. J., Peters, L., O'Connor, G. C. (2009), "Intra-organizational Networking for Innovation-Based Corporate Entrepreneurship." Journal of Business Venturing, Vol. 24, pp. 221-235.

Kirton, M. J. (1976), "Adaptors and Innovators: A description and Measure." Journal of Applied Psychology, Vol. 61, pp. 759-762.

Jackson, D. N. (1994), Jackson Personality Inventory - Revised Manual. Port Heron, MI: Sigma Assessment Systems. Systems, Inc.

Lukeš, M., Jakl, M. (2012), Podnikání v české republice. Praha: Oeconomica, 2012.

Lukeš, M., Stephan, U., Černíková, A. (2009), "Measuring Innovative Behavior and Innovation support." Paper presented at the $2^{\text {nd }}$ ISPIM Innovation Symposium, New York.

Lukeš, M., Stephan, U., Nový, I., Lorencová, H. (2010), "Innovative Behaviour of Individuals and its Support: The Views from Seven European and Asian Cultures." Paper presented at the $27^{\text {th }}$ ICAP Congress, Melbourne.

Miner, J. B. (2000), "Testing a Psychological Typology of Entrepreneurship Using Business Founders." Journal of Applied Behavioural Science, Vol. 36, No. 1, pp. 43-69.

Mueller, S. L., Thomas, A. S. (2000), "Culture and Entrepreneurial Potential: A Nine Country Study of Locus of Control and Innovativeness." Journal of Business Venturing, Vol. 16, pp. 51-75.

Rauch, A., Frese, M. (2007), "Let's Put the Person Back into Entrepreneurship Research: A Meta-Analysis on the Relationship Between Business Owners' Personality Traits, Business Creation and Success." European Journal of Work and Organizational Psychology, Vol. 16, pp. 353-385.

Rauch, A. (2010), "Dispositions of Entrepreneurs: Exploring Entrepreneurs' Personality Characteristics." In M. Lukes, M. Laguna (Eds.), Entrepreneurship: A Psychological Approach (pp. 37-54), Prague: Oeconomica.

Rosenbusch, N., Brinckmann, J., Bausch, A. (2011), "Is Innovation Always Beneficial? A Meta-Analysis of The Relationship Between Innovation and Performance in SMEs." Journal of Business Venturing, Vol. 26, No. 4, pp. 441-457.

Scott, S. G., Bruce, R. A. (1994), "Determinants of Innovative Behaviour: A Path Model of Individual Innovation in the Workplace." Academy of Management Journal, Vol. 37, No. 3, pp. 580-607.

Shane, S., Venkataraman, S., MacMillan, I. (1995), "Cultural differences in Innovation Championing Strategies." Journal of Management, Vol. 21, pp. 931-952.

Shane, S. A., Kolvereid, L., Westhead, P. (1991), "An Exploratory Examination of the Reasons Leading to New Firm Formation across Country and Gender." Journal of Business Venturing, Vol. 6, pp. 431-446.

Schumpeter, J. (1934), "The Theory of Economic Development." Cambridge, MA: Harvard University Press. (Translation of the original German work titled Theorie der Wirtschaftlichen Entwicklung)

Stevenson, H. H., Jarillo, J. C. (1990), "A Paradigm of Entrepreneurship: Entrepreneurial management." Strategic Management Journal, Vol. 11, No. 4, pp. 17-27.

Tuunanen, M., Hyrsky, K. (1997), "Innovation Preferences Among Finnish and U.S. Entrepreneurs." Academy of Entrepreneurship Journal, Vol. 3, No. 1, pp. 1-11.

Utsch, A., Rauch, A., Rothfuss, R., Frese, M. (1999), "Who Becomes a Small Scale Entrepreneur in A Post-socialist Environment: On the Differences between Entrepreneurs and Managers in East Germany." Journal of Small Business Management, Vol. 37, No. 3, pp. 31-42.

Ward, W. T. (2004), "Cognition, Creativity, and Entrepreneurship." Journal of Business Venturing, Vol. 19, pp. 173-188.

West, M. A., Farr, J. L. (1989), "Innovation at Work: Psychological Perspectives." Social Behaviour, Vol. 4, pp. 15-30. 